
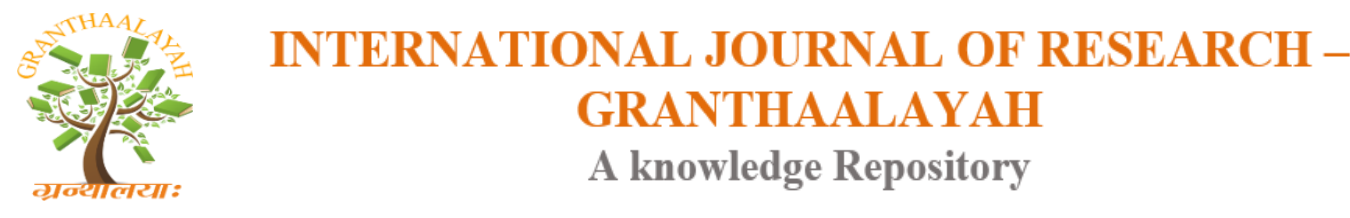

Social

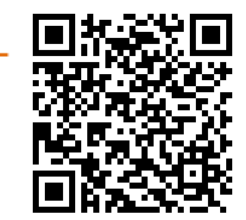

\title{
ACHIEVING GENDER EQUALITY, ECONOMIC JUSTICE AND COMPETITION LAW IN INDIA
}

\author{
Dr. Amit Kashyap ${ }^{1}$, Mr. Mohd. Jameel ${ }^{2}$ \\ ${ }^{1}$ Ph.D. UGC, NET/SRF, Assistant Professor, Department of Law, CUPB, Punjab-151001, India \\ ${ }^{2}$ Student of LL.M. 2nd Year, Department of Law, CUPB, Punjab-151001, India
}

\begin{abstract}
The Millennium Development Goals (MDG) on gender equality can be achieved by mainstreaming a gender perspective and promoting women's economic empowerment. Punjab has almost become synonymous with the low status of women, patriarchal society, feudal customs and values, social polarization along caste lines, high illiteracy, and poverty. The secondary status of women in Punjab coupled with an oppressive caste system and grinding poverty has robbed the women of their rights and a life of dignity, which were envisaged by the framers of the Constitution. The issue of gender equality has acquired a global character, and therefore, there is a need for the Civil Society to actively participate and enable the women to fight for their rights. The United Nations has included the issue of gender mainstreaming in the Millennium Declaration and 'promoting gender equality and empowerment of women' is one of the Millennium Development Goals (MDGs). Improved gender sensitivity could be achieved by adopting a proactive approach towards achieving gender economic justice. Therefore achieving gender equality requires two complementary approaches--mainstreaming a gender perspective and promoting women's economic empowerment.
\end{abstract}

Keywords: Competition; Efficiency; Regulation; Flourish; Economic Growth.

Cite This Article: Dr. Amit Kashyap, and Mr. Mohd. Jameel. (2018). "ACHIEVING GENDER EQUALITY, ECONOMIC JUSTICE AND COMPETITION LAW IN INDIA.” International Journal of Research - Granthaalayah, 6(3), 55-64. 10.29121/granthaalayah.v6.i3.2018.1498.

\section{Introduction}

Many think that competition policy and law are tools for the rich and urban society, while some raise eyebrows on the efficacy of competition policy and law in a society which is illiterate and poor. For example, the agricultural marketing order in India itself is so anti-competitive that too small farmers do not get the entire value of their produce, which is usually cornered by middlemen.

This is aided by archaic laws, which the state governments in India are unenthusiastic to modify, probably to satisfy some vested interests. To address these misconceptions, we recount the tale of 
a poor peasant widow, who used the law to get redressal against another scourge of our society, the moneylender, and the conspiracy, which prevails, in our community. ${ }^{1}$

Rukmini Devi, a poor, elderly illiterate widow, lives in a village near Chittorgarh in Rajasthan. She had to sow her unirrigated 5-bigha farm in time but did not have the resources to buy the seeds, fertilizer, etc. Favourably, soft loans were available at the local cooperative bank situated at Rashmi, the sub-divisional headquarters under the government's integrated rural development scheme. Given the frauds which are ubiquitous, illiterates are required to affix two passport-size photographs to the loan documentation. Rukmini approached in one of the two studios to take her photo. Meanwhile, when she went to collect the picture, she was given one reason or the other for the non-delivery of the photograph and when approached the other studio did not help. That indicated that she could not get the easy loan. As a result, she was compelled to go back to the mean money lender to get the money, because rain god would not have waited for her loan. Both the studios acted in alliance with the moneylender.

Through a local consumer activist, she complained to the local district forum under the Consumer Protection Act against the restrictive trade practice and the cartelized action that the two studios were engaged. She won the case and got damages from the studio, and the cartel did break. This real-life example shows how cartels can operate at all levels in the country and sap the people and the economy. It also shows that the poor do benefit from action against competition abuses if they can access justice. The same situation can do projected onto the more substantial national canvas. But new laws such as the Competition Act, 2002, alone cannot break cartels; we need commensurate policies to ensure that competition prevails, and the people benefit. $^{2}$

India took up economic reforms in the early 1990s, and till 2002, did not have a specific law dealing with antitrust issues. It was in this context that separate legislation dealing with competition and antitrust matters was considered necessary and the Competition Act, 2002, was passed. Enacted to fulfill India's obligations under the WTO agreements, the Act replaced the then existing Monopolies and Restrictive Trade Practices Act, 1969, which was considered inadequate to meet the objectives of competition policy. Following the 2007 Amendment, the Competition Commission grew a market regulator, and the Competition Appellate Tribunal did establish. The 2009 amendment rendered for a mechanism to dispose of the cases pending before the MRTP Commission.

The chief objective of competition law is to ensure free, fair and healthy competition in the market. Competition law holds on the basis that the free interplay of the competitive forces in the market which will yield the best allocation of economic resources, lower prices, improve quality and maximum material progress for the consumers. Thus, the principal objective of the Competition Law is to make the market economy work better by stopping vested interests from obstructing markets. Therefore the purpose is to maintain and protect the competitive process. The advantages of competition for economic growth and consumer welfare are well understood, and therefore, strict enforcement of competition law is a big test for any competition authorities. The competition law prohibits and penalizes anti-competitive practices by enterprises functioning in the market, i.e., addresses market failures whereas competition policy seeks to correct the anti-competitive outcomes of various government policies and laws and help in the 
development of competitive markets. ${ }^{3}$ Competition law aims to protect competition in the market as a means of enhancing consumer welfare and ensuring the efficient allocation of resources. Therefore, the principal aim of the Act, regarding its preamble and statement of objects and reasons, is to eliminate practices which are having adverse effects on the competition and promoting and sustain competition in the market. To protect the interests of the consumers and ensure freedom of trade carried on by the participants in the market, given the economic developments of the country.

\section{Competition and Poverty Eradication ${ }^{4}$}

We are lasting in an era of market-driven globalization, in a world frequently interdependent and with unusual openness in the global economy. A world in which the bulk of trade and economic growth has no precedent in history. That is an era, which, though mostly useful, has also brought about poverty and inequalities in wealth and possibilities for the people and small and medium economic players in the markets. It is also an era that needs to translate these positive aspects into gains for developing countries and particularly their people. Today, poverty is one of the most significant difficulties faced by the developing countries. The phrase "living on less than a dollar a day" has sneaked into modern literature, news items, journals and other media to describe the terrible anguish of the poor in world populations. In this connection, the Millennium Development Goals, and in particular poverty alleviation/reduction and eradication, comprise a subject that has remained raised in profile. It features among the top priorities of all international organizations and governments for policy implementation Poverty has enhanced a subject of study by the research institutions and individuals. It has also moved and recognized as one of the most critical areas for assuring consistency and regulating global and domestic policies. Poverty is a reality in almost all the countries at different dimensions and measures, and the rejection of it in any context negatively affects the efforts made in dealing with it. The existence of poverty remains associated with many causes including government policies, poor planning, and nonmotivation. Nonetheless, the purpose of poverty notwithstanding, its alleviation is perceived to emanate from some policy interventions. Therefore, it is necessary for governments to know the poor, what they need and where they stand.

The specific factors have signified as a cause of poverty in the developing countries. That include lack of progressive economic growth due to other factors, for instance, the prevalence of diseases like HIV/AIDS, high population growth rates, lack of infrastructure support, etc. The debt burden perpetuates poverty in many developing countries where a large percentage of GDP goes to debt servicing, leaving limited resources to tackle poverty-related issues. The other possible factors could be associated with high inequality in income between the rich and the poor, or between those who can exploit the available opportunities and those who are not. Disparities could do based on rural-urban, inter-racial and inter-social factors, climatic conditions, access to markets and historical factors.

In connection with this, many authors have studied the pro-growth and pro-poor benefits of competition in the markets, finding indications that economies with competitive domestic markets manage to have higher per capita income and increase rates. International competition has seen a period of accretion, and now that interdependence of national economies has risen to a point where all economies do expose to the control of affairs and policies originating in other 
parts of the globe. The widely accepted economic notion is barriers to competition which impede innovation, growth, prosperity and continued to some extent by the increase of policy and law actions dispensing with the competition at both national and regional levels. Having this in mind, in a spirit of constant coherence, the United Nations took the step of adopting in 1980 the UN Set of Multilaterally Agreed Equitable Principles and Rules for the Control of Restrictive Business Practices. The adoption of the UN Set has done widely received as a critical effort in connection at a global level as it is the only multilateral tool on competition policy for giving a set of rules for the administration of anti-competitive practices. Imperatively, these rules also see the development dimension of competition law and policy and provide a structure for international cooperation and exchange of best practice. It is necessary to recollect that UNCTAD is the focal point on all capacity building and for the technical assistance work related to the competition policy and consumer protection within the United Nations system.

In this regard, assessing the actual contributions and the potential implications of competition in poverty alleviation is a problematic exercise, mainly because the impact of competition on poverty alleviation, on welfare and the overall development likelihoods of developing countries remain an open debate. ${ }^{5}$ Expanding on the broad question of how to obtain gains from competition, ${ }^{6}$ promotes the idea that antitrust should not be used to protect inefficient small economic actors against the big players. It should be used to enable small economic actors against prominent actors by facilitating flow and market access, which in turn produce efficiencies in the society. Competition law and policy intervention have done advocated as policy tools to deal with poverty in developing countries. These instruments should take voluntary measures aimed at expanding the entrepreneurial base, through the prohibition of anticompetitive arrangements and the control of mergers/acquisitions, and at promoting effective competition in infrastructure industries. Energy, telecommunications, and financial markets are essential pillars of economic growth and which also add to the making of direct and indirect employment, which is a critical tool in alleviating poverty.

Experiences from developing countries have shown that prudent competition policy and law enforcement can assist specific vital sectors to accommodate/include more players. Many rural communities in developing countries, which entirely depend on the agricultural industry, are classified as weak. Therefore, a competition authority would pay attention to these sectors to tackle anti-competitive practices affecting them. Such intervention can, directly and indirectly, provide for wealth maintenance and the creation, which is key to poverty alleviation. Section 5 of the Competition Act, 2002 gives examples of some agricultural sub-sectors that can be recognized for intervention by competition policy and law. The analysis illustrates the contribution of competition law enforcement efforts in alleviating poverty, in the cotton, horticulture, floriculture, poultry and beef sectors and points to the fact that intervention has yielded positive results. ${ }^{7}$

\section{Basics of Competition Law}

The modern competition law seeks to protect the process of free-market competition to ensure efficient allocation of economic resources. 
There are core areas, as noted above, of enforcement that provide the focus for most competition laws in the world today. There are, however, differences in emphasis and interpretation across countries and over time within countries. The areas are not mutually exclusive, and there is considerable overlap between them.

The new law, Competition Act 2002 has essentially four compartments:

- Anti-Competitive Agreements

- Abuse of Dominance

- Combination Regulation

- Competition Advocacy ${ }^{8}$

\section{Anti-Competitive Agreements}

The Competition Act, 2002 has been passed to promote competition in India. The ultimate aim of competition law is to protect consumer welfare as competition in a market ensures that market players are looking to find the most efficient means of production resulting in excellent quality services and goods at lower prices. However, unlike the previous Indian competition law, the Monopolies and Restrictive Trade Practices Act (MRTP ACT), the Competition Act 2002 does not apply to all 'unfair trade practices'. So, while many consumer disputes would have come under the MRTP Act, the new Competition Act will not always apply to such cases. Section 3(1) of the Act prohibits and declares void any agreement between enterprises in respect of production, supply, distribution, storage, acquisition, or control of goods or provision of services, which causes, or is likely to cause an appreciable adverse effect on competition in India. Firms enter into agreements, which may have the potential of restricting competition. Contracts could be formal written documents or oral understandings, whether or not enforceable by legal proceedings. A search of the competition laws in the world will show that they make a distinction between "horizontal" (Agreement regarding prices, quantities, bids and market sharing) and "vertical" agreements (Tie-in arrangement, exclusive supply, distribution agreement and refusal to deal) between the firms. The former namely the horizontal agreements are those among competitors and the latter, agreements are those relating to an actual or potential relationship of purchasing or selling to each other. A particularly pernicious type of horizontal agreement is the cartel. Vertical agreements are pernicious if they are between firms in a position of dominance. Most competition laws view vertical agreements more leniently than horizontal agreements, as prima facie, horizontal agreements are more likely to reduce competition between firms in a purchaser-seller relationship.

In FICCI-Multiplex Association of India v. United ProducersWistributers Forum ${ }^{10}$ there was a collective decision of the opposite parties (producers and distributors of films) not to release films to the multiplexes to pressurize the multiplexes into accepting the new terms of revenue sharing ratio. The purpose was extracting better revenue sharing ratios from multiplexes. Thus the competition commission held that the agreement entered into by the opposite parties is covered within the mischief of clauses (A) and (b) of section 3(3) of the act and accordingly Rs.1 lakh held imposed on 27 parties each. 


\section{Abuse of Dominance}

The Competition Act, 2002 defines Dominance as a "Position of strength, enjoyed by an enterprise, in the relevant market, in India, which enables it to (1) operate independently of competitive forces prevailing in the relevant market, or (2) affect its competitors or consumers or the relevant market, in its favour". 11 This definition may perhaps appear to be somewhat ambiguous and to be capable of different interpretations by different judicial authorities. However, this ambiguity has a reason having a share of just 20 percent with the remaining 80 percent diffusely held by a large number of competitors which may be in a position to abuse its dominance. While a firm with say 60 percent market share with the remaining 40 percent held by a competitor may not be in a position to abuse its dominance because of the vital rivalry in the market. Specifying a threshold or an arithmetical figure for defining dominance may either allow real offenders to escape or result in unnecessary litigation. Hence, in a dynamic changing economic environment, a static arithmetical figure to define "dominance" may perhaps be an aberration. With the board above definition, the Regulatory Authority under the Act, namely, the Competition Commission of India (CCI) will have the freedom to fix errant undertakings and encourage competitive market practices, even if there is a large player around. Abuse of dominance is the key to Act, in so far as dominant enterprises are concerned. It is necessary to note that the Act did design in such that its provisions on this count only take effect if dominance remains established. ${ }^{12}$

To draw the provisions of this Act, it needs to do established whether the restraints create a barrier to new entry or force existing competitors out of the market. The critical issue is the extent to which these arrangements foreclose the market to manufacturers or retailers and the extent to which these raise rivals costs and dampen existing competition. The costs of such arrangements need to do weighed against the benefits. Abuse of dominance having an appreciable adverse effect on competition occurs if an enterprise,

1) directly or indirectly, impose unfair or discriminatory-

- condition in purchase or sale of goods or service; or

- price in purchase or sale of goods or service

2) limits or restricts-

- production of goods or provision of services or market, therefore; or

- technical or scientific development relating to goods or services to the prejudice of consumers; or

3) indulges in practice or practices resulting in a denial of market access; or

4) Uses its dominant position in one relevant market to enter into, or protect other relevant market. ${ }^{13}$

In the case of Belair Owner Association v. DLF and Others ${ }^{14}$, the complainant was a group of apartment allottees who had entered into a standard form contract with DLF and alleged that DLF had imposed unfair and one-sided conditions in their standard form contract, which amounted to an Abuse of Dominance. It does allege that complainants had paid a substantial amount of money before signing the standard form contract and thus they had no option but to adhere to the terms of the contract. The CCI held that imposition of such terms amounted to an Abuse of Dominance under 4 (1) (a) of the competition act and imposed a penalty of Rs. 630 crores on DLF limited. 


\section{Combination Regulation}

Section 5 of the Act defined the term 'combination' which includes mergers, amalgamations, acquisitions and acquisition controls. The compartment dealing with combinations was one of the most debated ones among the four compartments in the Act. The Act makes it voluntary for the parties to notify their proposed agreement or combinations to the Mergers Bench (a part of the Competition Commission of India). The Act has made the notifications of combinations, voluntary and not mandatory and has laid down threshold limits for combinations to fall within its surveillance. The reason that compelled the Government to opt for voluntary notifications and for threshold limits merit mention. Section 6(1) prohibits any combination that causes or likely to cause, an appreciable adverse effect on competition within the relevant market in India. It declares that such a combination would be void. Section 6(2) sets out the procedure for the regulation of combinations.

The Act has made the pre-notification of combinations voluntary for the parties concerned. Though, if the parties to the combination prefer not to notify the CCI as it is not mandatory to notify it. They drive the risk of a post-combination action by the CCI. Subsequently, it does appear that the combination has an appreciable adverse effect on competition. The Act has listed several factors to occur into account to determine whether the combination would have the effect of or be likely to have an appreciable adverse effect on competition. The Regulatory Authority, namely, the Mergers Bench of the Competition of India is mandated to adjudicate on mergers by weighing potential efficiency losses against potential gains. ${ }^{15}$

\section{Competition Advocacy}

Section 49(3) of the Competition Act states that the Commission shall take suitable measures, as may be prescribed for the promotion of competition advocacy, creating awareness and imparting training about competition issues, and activities that could strengthen the competition culture in the market. The rules governing the advocacy role are to be made by the Central Government; these rules, when made, may be expected to provide further guidance on the scope and manner of undertaking advocacy by the Commission. Competition advocacy creates a culture of competition. There are many possible valuable roles for competition advocacy, depending on a country's legal and economic circumstances.

Competition advocacy has been an important area of activity of several competition authorities both regarding creating general awareness about the law amongst the enterprises and thereby promoting self-compliance and also regarding influencing government and regulatory policies in a pro-competition direction. The Competition Commission of India, regarding advocacy provisions in the Act, is enabled to participate in the formulation of the country's economic policies and to participate in the reviewing of the laws related to competition at the instance of the central government. The central government can refer to the Competition Commission of India for its opinion on the possible effect of a policy under formulation or of an existing law related to competition. To promote competition advocacy and create awareness about the competition issues and also to accord training to all concerned, the Act urges the establishment of a fund Christened as the competition fund. ${ }^{16}$ 


\section{Competition Law Policy}

Competition Policy is a broader term which includes all government policies and laws whereas competition law is a specific statute with a predefined mandate to adjudicate on the violation(s) of the law. It would last seen that competition law is a regulatory instrument to check the prevalence of anti-competitive practices whereas a competition policy is a proactive and positive effort to build a competition culture in an economy. Both competition law and competition policy are required to back the forces of competition in the market. The two complement each other. The competition law prohibits and penalizes anti-competitive practices by enterprises functioning in the market, i.e., addresses market failures. ${ }^{17}$ Some laws, regulations, and policies affect the state of competition. These regulations apply at all levels of government including local, regional, state, national and international, and cover all sectors. There can be no analysis of competition policy in the modern economy without considering the effects of regulations on competition. Many economists state that the effects on competition of anti-competitive regulations are greater than the effects of anti-competitive practices. It is this consideration which has given rise to the concept of comprehensive competition policy. A comprehensive competition policy includes all government policies (Trade policy, Industrial policy, Public sector and Privatization, Tax policy, Labour policy ${ }^{18}$ ) that affects the state of competition in any sector of the economy, and it includes:

- Fair pricing ${ }^{19}$

- Fair market process

- Removal of distortions and barriers

- Balancing competition and intellectual property rights

- Competition audit ${ }^{20}$

- Prohibition of anti-competitive conduct

- Liberal international trade policies

- Free movement of all factors of production

- Removing government regulation that limits competition

- The reform of inappropriate monopoly structures

- Appropriate access to essential facilities

- Separation of industry regulation from industry from industry operation, dominant firms should not set technical standards for new entrants. ${ }^{21}$

The conventional law prohibits anti-competitive conduct by business enterprises. It prohibits cartel conduct, abuse of dominance, anti-competitive mergers, and other anti-competitive practices and may extend to prohibition on false advertising and misleading and deceptive conduct.

\section{Conclusion and Suggestions}

- Rapid and continued poverty reduction requires pro-poor growth, i.e., a pace and pattern of growth that enhances the ability of poor women and men to participate in, contribute to and benefit from growth. Policies, therefore, need to promote both the pace of economic growth and its pattern, i.e., the extent to which the poor participate in growth as both agents and beneficiaries, as these do interweave, and both are critical for the long-term growth and sustained poverty reduction. 
- Policies to tackle the multiple dimensions of poverty, including the cross-cutting dimensions of gender and environment, are mutually reinforcing and should go hand-inhand. Progress in one dimension will remain accelerated by progress in others. In tackling poverty, perceptions of policy dichotomies have been misplaced. Policy tradeoffs do exist but can be better managed.

- Empowering the poor is essential for bringing about the policies and investments needed to promote pro-poor growth and address the multiple dimensions of poverty. To achieve this, the state and its policy-making processes need to open, transparent and accountable to the interests of the poor. Policies and resources need to help expand the economic activities of the poor.

- Both the pace and the pattern of growth are critical for long-term and sustainable poverty reduction.

- A pro-poor of growth makes growth more effective in reducing poverty.

- Inequality matters

- The vulnerability of the poor to risk and the lack of social protection reduce the pace of growth and the extent to which it is pro-poor.

- Policies need to tackle the causes of market failure and improve market access.

- Policies to tackle the multiple dimensions of poverty should go hand-in-hand

- Policy trade-offs still exist but can be better managed.

- Competition law should not stand alone but should be part of a well-designed package of measures to create the right environment to allow competitive markets to benefits the poor.

- The focus of competition law should stay as close as possible to the objective of fostering competition in markets.

- A competition authority should be independent of government in its day-to-day decisions. ${ }^{22}$

\section{References}

[1] Mehta S. Pradeep and Agarwal Manish CUTS International, Does Competition Law Help the Poor, The Economic Times, October 28, 2005, https://economictimes.indiatimes.com/editorials/does-competition-law-help-thepoor/articleshow/1277758.cms, Accessed on 17 January, 2018

[2] Mehta S. Pradeep and Agarwal Manish CUTS International, Time for a Functional Competition Policy and Law in India, CUTS Centre for Competition, Investment and Economic Regulation, http://www.cuts-international.org/pdf/compol.pdf, Accessed on 17 January, 2018

[3] Mehta, S. Pradeep. Why Should Consumers be Interested in Competition Law \& Policy? CUTS International Jaipur. Retrieved from

http://www.cuts-ccier.org/pdf/why_should_consumers_be_interested in_a_competition_law _and_policy.pdf, Accessed on 8 December 2017

[4] Hassan Qaqaya George Lipimile. The Effects of Anti-Competitive Business Practices on Developing Countries and Their Development Prospects, UN Conference on Trade and Development, UN New York and Geneva, 2008, Accessed on 17 January, 2018

[5] Available at: http://unctad.org/en/Pages/DITC/CompetitionLaw/The-United-Nations-Set-ofPrinciples-on-Competition.aspx, accessed on 17 January, 2018

[6] Section 4 of The Competition Act, 2002.

[7] Hassan Qaqaya George Lipimile. Supra note 4 (pp.9-12). 
[8] Chakravarthy, S. (2006). Competition Act, 2002: The Approach. Mehta, S Pardeep. (Ed.), A Functional Competition Policy For India,(p.55).New Delhi, Academic foundation with CUTS International

[9] Ibid, 56.

[10] Case No. 01/ 2009 Order dated 25-5-2011(Competition Commission of India )

[11] Rab, Suzanne. (2012). Indian Competition Law an international perspective. (p.26).Gurgaon, Wolters Kluwer (India) Pvt Ltd.

[12] Chakravarthy, S. Supra note 3. (p.59).

[13] Chakravarthy, S. Supra note 3.

[14] Case no. 19/ 2010, Order dated 12-08-2011(Competition Commission of India)

[15] Chakravarthy, S. Supra note 3. (p. 62).

[16] Chakravarthy, S. Supra note 3. (p. 63).

[17] National Competition Policy 2005. Retrieved from <http://www.mca.gov.in/Ministry/pdf/Draft_ National_Competition_Policy .pdf,>Accessed on 9 December 2017

[18] Anant, TCA. \& Singh, Jaivir. (2006). Central Government Policies: Interface With Competition Policy Objectives. Mehta, S Pardeep. (Ed.), A Functional Competition Policy For India. (pp.108109).New Delhi, Academic foundation with CUTS International.

[19] National Competition Policy 2011, Retrieved from<http://www.mca.gov.in/Ministry/pdf/Draft_ National_Competition_Policy.pdf,>Accessed on 9 December 2017

[20] National competition policy, Supra note 11.

[21] Fels, Allan. (2007). Competition and Regulation. Dhall, Vinod. (Ed.), Competition Law Today. (pp.195-197,206).New Delhi, Oxford University Press.

[22] "Implementing Competition Policy in Developing Countries", in Promoting Pro-Poor Growth: Policy Guidance for Donors, OECD (2007)

http://www.oecdilibrary.org/docserver/download/4307081ec009.pdf?expires=1471518487\&id=id $\&$ accname $=$ guest $\&$ checksum $=59 F 109306 F 2 E B 81 C 2 B D 329407 E 46 F 290$, accessed on 18-012018

\footnotetext{
*Corresponding author.

E-mail address: amit_jura@ yahoo.co.in/ jameelinqalabi786@ gmail.com
} 